\title{
Magnetic cathode stimulates extracellular electron transfer in bioelectrochemical systems
}

Zhou, Huihui; Zhang, Dawei; Zhang, Yifeng; Yang, Yang; Liu, Bing-Feng; Ren, Nanqi; Xing, Defeng

Published in:

ACS Sustainable Chemistry and Engineering

Link to article, DOI:

10.1021/acssuschemeng.9b03461

Publication date:

2019

Document Version

Peer reviewed version

Link back to DTU Orbit

Citation (APA):

Zhou, H., Zhang, D., Zhang, Y., Yang, Y., Liu, B-F., Ren, N., \& Xing, D. (2019). Magnetic cathode stimulates extracellular electron transfer in bioelectrochemical systems. ACS Sustainable Chemistry and Engineering, $7(17), 15012-15018$. https://doi.org/10.1021/acssuschemeng.9b03461

\section{General rights}

Copyright and moral rights for the publications made accessible in the public portal are retained by the authors and/or other copyright owners and it is a condition of accessing publications that users recognise and abide by the legal requirements associated with these rights.

- Users may download and print one copy of any publication from the public portal for the purpose of private study or research.

- You may not further distribute the material or use it for any profit-making activity or commercial gain

- You may freely distribute the URL identifying the publication in the public portal 


\section{Article}

Subscriber access provided by DTU Library

\section{Magnetic cathode stimulates extracellular electron transfer in bioelectrochemical systems}

Huihui Zhou, Dawei Zhang, Yifeng Zhang, Yang Yang, Bing-Feng Liu, Nanqi Ren, and Defeng Xing

ACS Sustainable Chem. Eng., Just Accepted Manuscript • DOI: 10.1021/ acssuschemeng.9b03461 - Publication Date (Web): 02 Aug 2019

Downloaded from pubs.acs.org on August 5, 2019

\section{Just Accepted}

"Just Accepted" manuscripts have been peer-reviewed and accepted for publication. They are posted online prior to technical editing, formatting for publication and author proofing. The American Chemical Society provides "Just Accepted" as a service to the research community to expedite the dissemination of scientific material as soon as possible after acceptance. "Just Accepted" manuscripts appear in full in PDF format accompanied by an HTML abstract. "Just Accepted" manuscripts have been fully peer reviewed, but should not be considered the official version of record. They are citable by the Digital Object Identifier (DOI®). "Just Accepted" is an optional service offered to authors. Therefore, the "Just Accepted" Web site may not include all articles that will be published in the journal. After a manuscript is technically edited and formatted, it will be removed from the "Just Accepted" Web site and published as an ASAP article. Note that technical editing may introduce minor changes to the manuscript text and/or graphics which could affect content, and all legal disclaimers and ethical guidelines that apply to the journal pertain. ACS cannot be held responsible for errors or consequences arising from the use of information contained in these "Just Accepted" manuscripts. 


\title{
Magnetic cathode stimulates extracellular
}

\section{electron transfer in bioelectrochemical}

\section{systems}

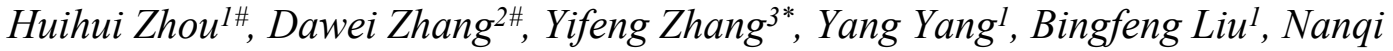 \\ Ren $^{1}$, Defeng Xing ${ }^{1 *}$
}

${ }^{1}$ State Key Laboratory of Urban Water Resources and Environment, School of

Environment, Harbin Institute of Technology, Harbin 150090, China

${ }^{2}$ State Key Laboratory of Tree Genetics and Breeding, Northeast Forestry University, Harbin 150006, China

${ }^{3}$ Residual Resource Engineering, Department of Environmental Engineering, Technical University of Denmark, Bygningstorvet, 2800, Kgs. Lyngby, Denmark \# These authors have contributed equally to this work.

* Corresponding author. School of Environment, Harbin Institute of Technology, P.O. Box 2614, 73 Huanghe Road, Nangang District, Harbin, Heilongjiang Province 150090, China

Tel: +0086-451-86283123; E-mail address: yifz@env.dtu.dk,dxing@hit.edu.cn

\begin{abstract}
Exploring alternative cathodic catalysts capable of highly catalytic activity is crucial to the expansion of bioelectrochemical systems. Herein, $\mathrm{Fe}_{3} \mathrm{O}_{4} @ \mathrm{~N}-\mathrm{mC}$ is developed as a magnetic cathode catalyst for bioelectroreduction of oxygen. The $\mathrm{Fe}_{3} \mathrm{O}_{4} @ \mathrm{~N}-\mathrm{mC}$ exhibits better electrocatalytic activity, selectivity (four electron transfer
\end{abstract}


pathway), and long-term electrochemical stability in neutral solutions compared to commercial Pt/C catalyst. The microbial fuel cell using $\mathrm{Fe}_{3} \mathrm{O}_{4} @ \mathrm{~N}-\mathrm{mC}$ generates a power density of $1141 \mathrm{mWm}^{-2}$, which is higher than that of using $\mathrm{Pt} / \mathrm{C}\left(1022 \mathrm{mWm}^{-2}\right)$. Furthermore, the decline of power density is much lower in reactor with $\mathrm{Fe}_{3} \mathrm{O}_{4} @ \mathrm{~N}-\mathrm{mC}$ (4\%) than with $\mathrm{Pt} / \mathrm{C}(8 \%)$. With $\mathrm{Fe}_{3} \mathrm{O}_{4} @ \mathrm{~N}-\mathrm{mC}$, the cell also obtains higher coulombic efficiency (26\%) than that with Pt/C (21.7\%). The outstanding electrocatalytic activity and stability of $\mathrm{Fe}_{3} \mathrm{O}_{4} @ \mathrm{~N}-\mathrm{mC}$ show its great potential to be a favorable substitute to $\mathrm{Pt} / \mathrm{C}$ catalysts in microbial electrochemical energy devices.

Keywords : Encapsulated $\mathrm{Fe}_{3} \mathrm{O}_{4}$ nanoparticles; Magnetic cathode; Extracellular electron transfer; Oxygen reduction reaction; Bioelectrochemical systems

\section{Introduction}

The fast growth of global population and depletion of natural energy resources has caused overwhelming demand on the exploration of environmentally friendly and sustainable energy. Bio-battery such as microbial fuel cells (MFCs) have captured huge notice lately as superior eco-friendly biotechnology for recovering energy from biodegradable wastes. ${ }^{1,2}$ Exoelectrogenic bacteria in the MFC anode boost the decomposition of biodegradable organic matter and then pass the resulting electrons and protons to the electron receptors on the cathode. ${ }^{3}$ Oxygen $\left(\mathrm{O}_{2}\right)$ is regarded as an ideal terminal electron acceptor due to its high reduction potential $(1.229 \mathrm{~V})$, clean product, and prepared accessibility. ${ }^{4}$ There are two pathways for the oxygen reduction reaction (ORR) process. One is to reduce oxygen to $\mathrm{H}_{2} \mathrm{O}$ directly via a four-electron pathway, and another one is to reduce oxygen first to $\mathrm{H}_{2} \mathrm{O}_{2}$ and then further be reduced to $\mathrm{H}_{2} \mathrm{O}$ through a two-electron pathway. So, the four-electron pathway is more efficient and desirable in terms of energy recovery. ${ }^{5}$ One of obstacles for the practical 
implementations of air-cathode MFCs is the sluggish kinetics of ORR. ${ }^{6,7}$ Traditionally, platinum and its alloys can attain the ORR in four-electron pathway by reducing the overpotential, and thereby resulting in high-efficiency energy recovery and power output. Nevertheless, their high capital cost and susceptibility to time-dependent drift compromise their extensive utilization and commercialization. ${ }^{8-10}$ Thus, great efforts have been done to explore cost-effective materials that possess comparable catalytic performance to platinum for the ORR in cathode.

Non-precious metal catalysts (NPMCs) with distinguish catalytic ORR activity, good stability and popular price have received increasing attention. Among which, nitrogendoped carbon materials are regarded as favorable catalysts because they can promote the $\mathrm{O}_{2}$ adsorption, increase active sites and improve the surface hydrophobicity, in addition to its high electrical conductivity and oxidation stability. ${ }^{11}$ As reported previously, nitrogen species can conduct a four-electron transfer process, which can reduce the $\mathrm{O}-\mathrm{O}$ bond and could function as the active sites in ORR process. ${ }^{12}$ Nevertheless, most of the pure nitrogen-doped catalysts showed less ORR activity than $\mathrm{Pt} / \mathrm{C}$ catalysts. Thus, it has been further integrated with nonprecious metals (especially, cobalt or iron) to enhance the ORR activity, endurance to poisons, and the durability. Recent studies have shown that the transition metal encapsulated within nitrogen-doped graphitic carbon layer to form a core-shell structured catalyst was a good substitute for Pt/C. ${ }^{13,14}$ In our previous study, we synthesized a core-shell structure Fe-N-C catalyst, which performed higher ORR activity than its intermediates, including N-C. ${ }^{15}$ The outstanding ORR activity of Fe-N-C catalyst compared to N-C can be ascribed to two reasons: (1) Fe-N coordination is generally regarded as the active sites in ORR process, which led a four-electron transfer pathway; ${ }^{16}$ (2) Fe acted as the catalyst in the carbon graphitization process increased the graphitic structures of the hybrid, resulting in 
improving electrical conductivity and catalytic activity. ${ }^{17}$ While the iron core of Fe-NC catalyst in our previous work was too big (around $400 \mathrm{~nm}$ ) to sufficiently interact with the surrounding $\mathrm{N}$ or $\mathrm{C}$, which limits its optimal ORR performance. In view of catalyst design, the introduction of high dispersion $\mathrm{Fe}_{3} \mathrm{O}_{4}$ nanoparticles was expected to increase the Fe- $\mathrm{N}$ active sites and graphitic carbon to enhance the catalytic activity of Fe-N-C catalyst in ORR process.

Recent studies proved that magnetic anode and pulse electromagnetic fields enhanced the extracellular electron transfer (EET) of bioelectrochemical systems (BESs). ${ }^{18,19} \mathrm{We}$ hypothesize that magnetic materials at the cathode might impact EET of BESs. Herein, we developed a magnetic core-shell structure catalyst $\left(\mathrm{Fe}_{3} \mathrm{O}_{4} @ \mathrm{~N}-\mathrm{mC}\right)$, in which $\mathrm{Fe}_{3} \mathrm{O}_{4}$ nanoparticles of around $8 \mathrm{~nm}$ were embedded in mesoporous nitrogen-doped carbon. A comprehensive comparison between the $\mathrm{Fe}_{3} \mathrm{O}_{4} @ \mathrm{~N}-\mathrm{mC}$ and the $\mathrm{Pt} / \mathrm{C}$ catalysts was conducted in catalytic activity, power production and long-term electrochemical stability. The $\mathrm{Fe}_{3} \mathrm{O}_{4} @ \mathrm{~N}-\mathrm{mC}$ exhibited superior catalytic activity and stability to a commercial Pt/C catalyst, thus creating a new cost-effective catalyst for BESs.

\section{Experimental Section}

\section{Preparation and characterizations of $\mathrm{Fe}_{3} \mathrm{O}_{4} @ \mathrm{~N}-\mathrm{mC}$}

$\mathrm{Fe}(\mathrm{acac})_{3}(0.7 \mathrm{~g})$ was dissolved in triethylene glycol (TREG, 20mL), and then heated at $200{ }^{\circ} \mathrm{C}$ for $8 \mathrm{~h}$ to get $\mathrm{Fe}_{3} \mathrm{O}_{4}$ nanoparticles as previously reported. ${ }^{20} \mathrm{Fe}_{3} \mathrm{O}_{4}(100 \mathrm{mg})$ was added to $1 \mathrm{~mol} / \mathrm{L}$ of hydrochloric acid $(100 \mathrm{~mL})$ which dissolved sodium dodecyl sulfate (SDS, 0.288g) and poly (ethylene oxide) ${ }_{20}$-block-poly (propylene oxide) $)_{70^{-}}$ block-poly (ethylene oxide) ${ }_{20}(\mathrm{P} 123,0.15 \mathrm{~g})$ in advance. After 30 minutes ultrasonically dispersed, the mixture was added with aniline $(0.36 \mathrm{~g})$ and ammonium persulfate $(0.9$ 
$\mathrm{g}$ ) in succession at $4{ }^{\circ} \mathrm{C}$ and vigorously stirred for $6 \mathrm{~h}$ to get $\mathrm{Fe}_{3} \mathrm{O}_{4} @ \mathrm{mPANI}$. Lastly, the obtained product was heated at $700{ }^{\circ} \mathrm{C}$ for $6 \mathrm{~h}$ in $\mathrm{N}_{2}$ atmosphere to obtain $\mathrm{Fe}_{3} \mathrm{O}_{4} @ \mathrm{~N}$ mC. Characterizations of $\mathrm{Fe}_{3} \mathrm{O}_{4} @ \mathrm{~N}-\mathrm{mC}$ were tested as previously descried. ${ }^{15}$ Details were shown in Supplementary Material.

\section{Electrochemical characterization of $\mathrm{Fe}_{3} \mathrm{O}_{4} @ \mathrm{~N}-\mathrm{mC}$}

The electrochemical property of catalysts were performed in a three electrode electrochemical cell using phosphate buffer saline as electrolyte (PBS, $50 \mathrm{mM}$ ), and furnished with a platinum sheet as counter electrode $\left(2.25 \mathrm{~cm}^{2}\right)$ and an $\mathrm{Ag} / \mathrm{AgCl}$ electrode as reference electrode. The current density was recorded at a scan rate of 10 $\mathrm{mV} \mathrm{s}^{-1}$ with varied rotation rate from 100 to $1600 \mathrm{rpm}$. The ORR property of the catalysts was analyzed on RRDE-3A apparatus (BAS Inc., Japan) with a scan rate of $10 \mathrm{mV} \mathrm{s}^{-1}$, and the rotating speed was varied from 400 to $3600 \mathrm{rpm}$ progressively. The glassy carbon (GC) working electrode was uniformly covered with a catalyst ink $(0.1$ $\mathrm{mg} \mathrm{cm}^{-2}$ ), which was prepared by dispersing $5 \mathrm{mg}$ electrocatalysts in $5 \mathrm{~mL}$ deionized (DI) water, then it was ultrasonicated for $30 \mathrm{~min}$. The electrode was fixed by adding 5 $\mu \mathrm{L}$ Nafion solution $(5 \mathrm{wt} \%$ ). The rotating ring-disk electrode (RRDE) tests were conducted at a constant ring potential of $1.0 \mathrm{~V}(\mathrm{vs} \mathrm{Ag} / \mathrm{AgCl})$ with a rotating speed of $1600 \mathrm{rpm}$. The electron transfer number $(\mathrm{n})$, kinetic current $\left(i_{K}\right)$, and peroxide yield $\left(\mathrm{H}_{2} \mathrm{O}_{2}\right)$ during ORR was calculated as previously reported. ${ }^{15}$

\section{Electrode Preparation and Operation Condition for MFCs}

The anode of MFC was carbon fiber brush. The gas diffusion layer (GDL) of MFC was made by rolling the mixture of carbon black and $60 \mathrm{wt} \%$ PTFE (mass ratio of 7:3) on a 
stainless steel mesh, then sintered at $340{ }^{\circ} \mathrm{C}$ for $30 \mathrm{~min}$. The catalyst layer (CL) was made by rolling the mixture of the catalysts and PTFE (mass ratio of $6: 1$ ) onto the opposite side of stainless steel according as previously reported. ${ }^{21}$ Single-chamber MFCs were constructed with an effective volume of $28 \mathrm{~mL} .{ }^{22}$ The cathode had a projected area of $7 \mathrm{~cm}^{2}$, which was connected with anode through a $1000 \Omega$ external resistance by external wire. Per liter of the culture solution contained sodium acetate (2g), phosphate buffer solution (PBS, $50 \mathrm{mM})$ mineral solution $(10 \mathrm{~mL})$, and vitamin solution $(10 \mathrm{~mL})$. Activated sludge in secondary clarifier of wastewater treatment plant (Harbin, China) serves as inoculum. The $\mathrm{Fe}_{3} \mathrm{O}_{4} @ \mathrm{~N}-\mathrm{mC}$ composites were tested as the cathodic catalysts for MFCs and commercial Pt/C (20 wt\%) was used $\left(5 \mathrm{mg} \mathrm{cm}^{-2}\right)$ for comparison. All MFC reactors were worked in fed-batch mode at the temperature of 30 $\pm 2{ }^{\circ} \mathrm{C}$.

\section{Analytical and electrochemical techniques of MFCs}

The cell voltages were recorded automatically every 10 min over an external resistance $(1000 \Omega$ ) by using a data acquisition system (Model 2700, Keithley Instruments Inc., USA) as previously reported. ${ }^{23}$ The electrochemical performances of the air cathode were tested by a potentiostat Autolab Potentiostat/Galvanostat (Autolab PGSTAT 128N, MetrohmAutolab Inc., Netherlands). LSV was performed from open circuit potential (OCP) to $-0.5 \mathrm{~V}$ with a scan rate of $1 \mathrm{mV} \mathrm{s}^{-1}$ while $50 \mathrm{mM}$ PBS solution was used as the electrolyte in the tested MFCs. LSV was tested in a three-electrode configuration, in which the air cathode was used as working electrode, an $\mathrm{Ag} / \mathrm{AgCl}$ electrode was used as reference electrode, and the anode was used as counter electrode. 
Changing the resistance of the external circuit from 3000 to $50 \Omega$ to get the polarization curve. The power density was calculated by using the equation of $\mathrm{P}=\mathrm{UI} / \mathrm{A}$, in which $\mathrm{U}$ stands for voltage, I stands for current, and A stands for the surface area of the cathode. Electrode (anode and cathode) potentials were recorded during polarization test by using $\mathrm{Ag} / \mathrm{AgCl}$ reference electrode. The APHA standard method was used to measure the chemical oxygen demand (COD) of reactors. Coulombic efficiency (CE) was the percentage of practical electron charge produced in one cycle versus the available electrons from substrate metabolism. ${ }^{24}$

\section{Results and discussion}

\section{Structure characteristics}

The TEM image shows $\mathrm{Fe}_{3} \mathrm{O}_{4}$ nanoparticles obtained in the first step are about $8 \mathrm{~nm}$ in diameter, and with good dispersing property (Fig. 1a). The observed morphology of $\mathrm{Fe}_{3} \mathrm{O}_{4} @ \mathrm{~N}-\mathrm{mC}$ indicates that the catalyst was uniformly dispersed as expected (Fig. 1b). The flocculates with lamellar structure can be seen as the graphite layers embedding many small dark particles belonged to $\mathrm{Fe}_{3} \mathrm{O}_{4}$. SEM images revealed the catalyst had mesoporous spherical morphologies with nano-sized pores (Fig. 1c). Thus, the product might be consisted of a carbon shell and $\mathrm{Fe}_{3} \mathrm{O}_{4}$ core. The element mapping images demonstrate the existence of C (Fig. 1d), Fe (Fig. 1e) and N (Fig. 1f) elements. The surface area and porous structure of $\mathrm{Fe}_{3} \mathrm{O}_{4} @ \mathrm{~N}-\mathrm{mC}$ were measured by nitrogen adsorption-desorption isotherms. A typical type-IV isotherm was attributed to its mesoporous structure. The BET surface area was $154.3 \mathrm{~m}^{2} \mathrm{~g}^{-1}$ and a uniform mesoporous size distribution with an average size of $4.2 \mathrm{~nm}$ was obtained from analysis of the desorption curve (Fig. S1). The mesoporous structure was beneficial to the 
accessibility of active sites and facilitates mass transfer kinetics.

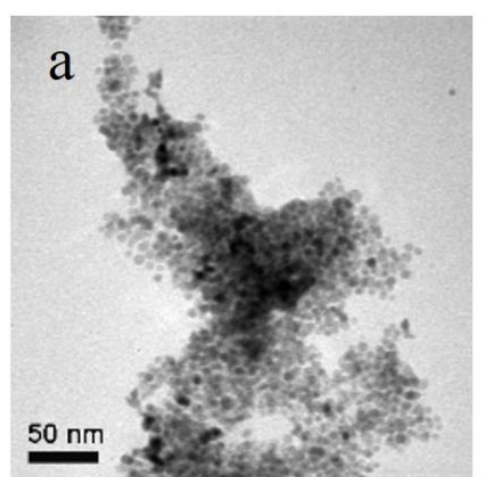

$\mathrm{C}$ Ko1_2

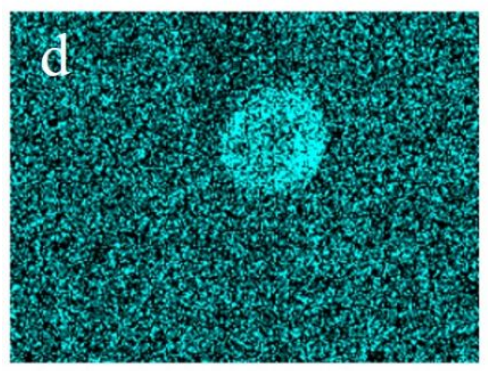

$\longdiv { 5 0 0 \mathrm { nm } }$

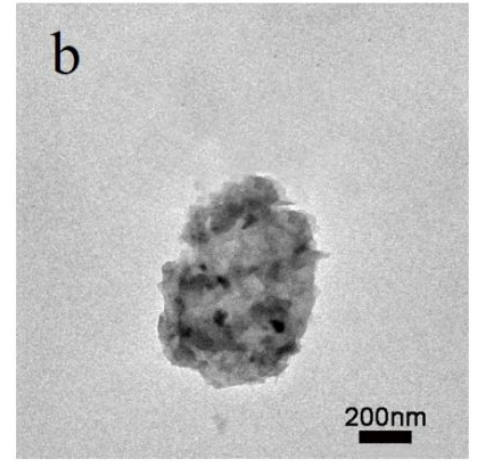

Fe $K \alpha 1$

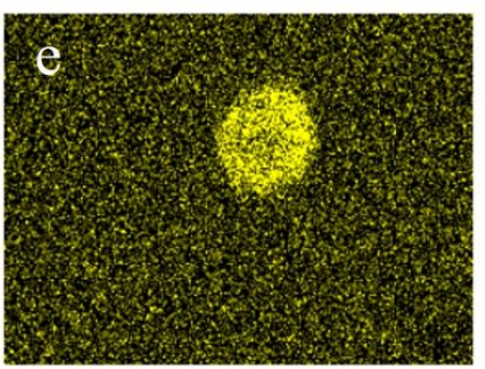

$\longdiv { 5 0 0 \mathrm { nm } }$

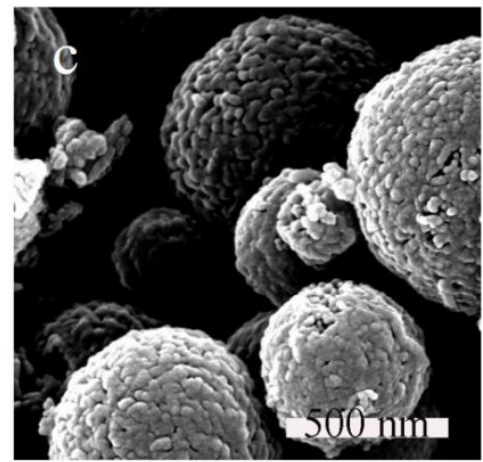

N Ka1_2

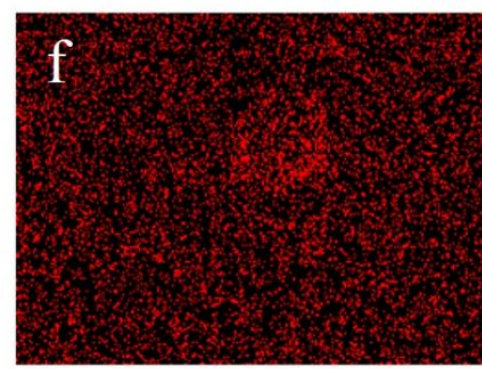

$\longdiv { 5 0 0 \mathrm { nm } }$

Fig. 1 TEM images of $\mathrm{Fe}_{3} \mathrm{O}_{4}(\mathrm{a})$ and $\mathrm{Fe}_{3} \mathrm{O}_{4} @ \mathrm{~N}-\mathrm{mC}$ (b); $\mathrm{SEM}(\mathrm{c})$ image of $\mathrm{Fe}_{3} \mathrm{O}_{4} @ \mathrm{~N}-$ $\mathrm{mC}$; the element mapping images for $\mathrm{C}(\mathrm{d}), \mathrm{Fe}(\mathrm{e})$ and $\mathrm{N}(\mathrm{f})$ of $\mathrm{Fe}_{3} \mathrm{O}_{4} @ \mathrm{~N}-\mathrm{mC}$.

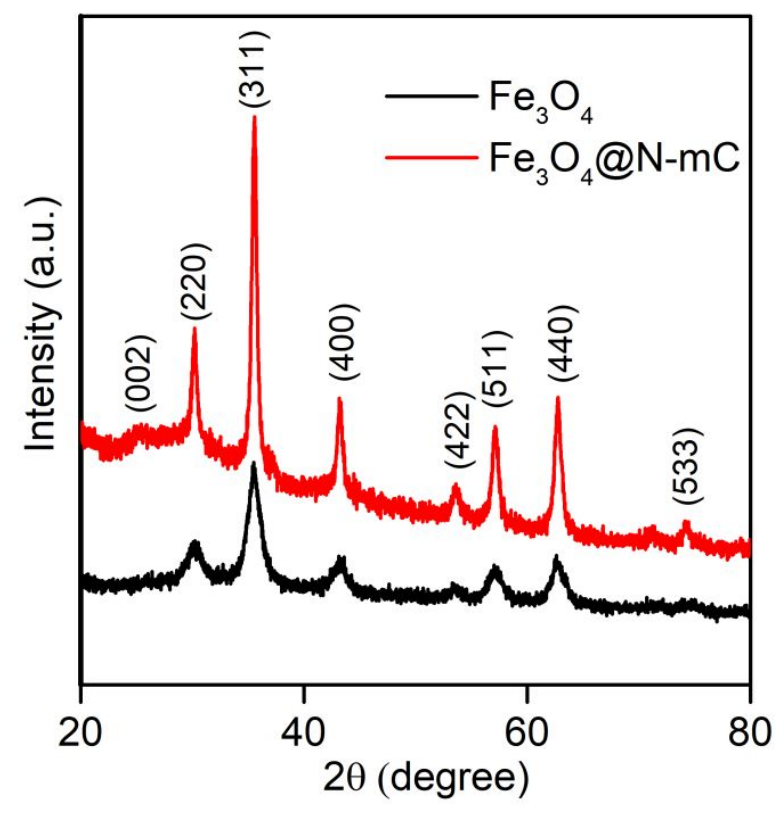

Fig. 2 XRD analyses of the main crystalline phases in $\mathrm{Fe}_{3} \mathrm{O}_{4}$ and $\mathrm{Fe}_{3} \mathrm{O}_{4} @ \mathrm{~N}-\mathrm{mC}$ composite. 
The microstructure of $\mathrm{Fe}_{3} \mathrm{O}_{4} @ \mathrm{~N}-\mathrm{mC}$ was further verified by the XRD (Fig. 2). There were seven distinct diffraction peaks corresponds to the (220), (311), (400), (422), (511), (440), and (533) of $\mathrm{Fe}_{3} \mathrm{O}_{4}$ (JCPDS No. 65-3107), which confirmed the existence of $\mathrm{Fe}_{3} \mathrm{O}_{4}$ in the hybrid. The peak observed at around $25.5^{\circ}$ belonged to the (002) planes of graphitic carbon and it should be ascribed to the iron nanoparticles playing as the graphitization catalyst to improve the graphitization degree of carbon layer during pyrolysis. ${ }^{17,25}$ The existence of the graphitic carbon was also verified by Raman spectroscopy (Fig. S2). The signal peaks showed a G band and a weaker D band at around $1595 \mathrm{~cm}^{-1}$ and $1343 \mathrm{~cm}^{-1}$, respectively. The G-band was usually ascribed to the stretching of $\mathrm{sp}^{2}$-bonded on carbocycle or long-chain of ordered graphite, whereas, the D-band is related to defects in the graphite. ${ }^{26}$ Therefore, the G/D intensity ratio was regarded as a measurement for order quantity in graphitic materials. The $\mathrm{I}_{\mathrm{G}} / \mathrm{I}_{\mathrm{D}}$ ratio of $\mathrm{Fe}_{3} \mathrm{O}_{4} @ \mathrm{~N}-\mathrm{mC}$ was 1.19, which indicated more order crystalline graphite and could be beneficial for ORR since it increases the electricity conductivity of the derived carbon. ${ }^{8}$

The XPS analysis revealed the content and chemical state of elements on $\mathrm{Fe}_{3} \mathrm{O}_{4} @ \mathrm{~N}-$ $\mathrm{mC}$ (Fig. 3). The survey scan of $\mathrm{Fe}_{3} \mathrm{O}_{4} @ \mathrm{~N}-\mathrm{mC}$ showed that there were four kinds of elements, carbon (81.28\%), oxygen (10.08\%), nitrogen (5.01\%), and iron (3.63\%) (Fig. 3a). The XPS survey of $\mathrm{C} 1 \mathrm{~s}$ declared four kinds of $\mathrm{C}$ function group ascribed to $\mathrm{C}=\mathrm{C}$ (284.8 eV), C-O (286 eV), C=O or C=N (287.5 eV), and C-N (289.9 eV) (Fig. 3b). It is generally believed that peak ascribed to $\mathrm{C}=\mathrm{O}$ and $\mathrm{C}=\mathrm{N}$ indicated the nitrogen is successfully doped into the carbon matrix. ${ }^{27}$ The high-resolution N1s spectra were fitted with three peaks at $398.4 \mathrm{eV}, 399.5 \mathrm{eV}$, and $401 \mathrm{eV}$, belonging to pyridinic $\mathrm{N}$, pyrrolic $\mathrm{N}$, and graphitic $\mathrm{N}$, respectively (Fig. 3c). ${ }^{28}$ In addition, the difference of binding energies between Fe-N and pyridinic $\mathrm{N}$ is slight, 

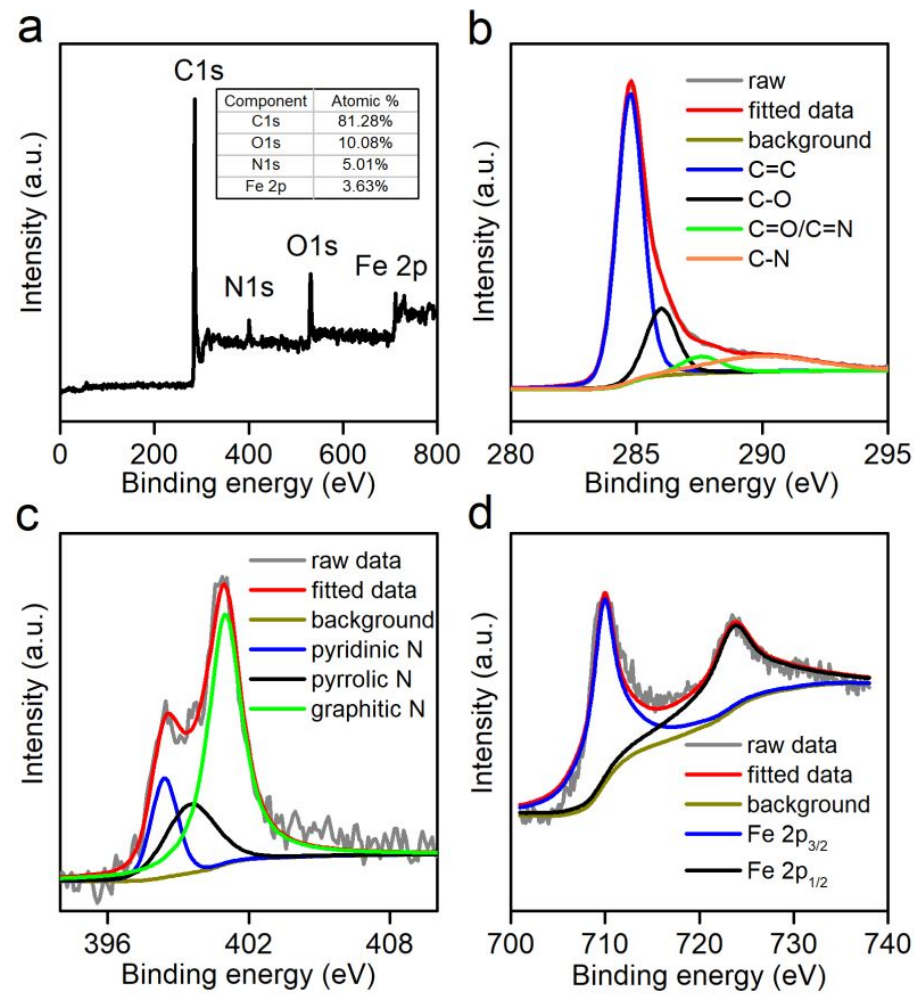

Fig. 3 XPS survey spectrum (a) and high-resolution C1s (b), N1s (c) and Fe 2p (d) spectra of $\mathrm{Fe}_{3} \mathrm{O}_{4} @ \mathrm{~N}-\mathrm{mC}$ catalyst.

so the peak at $398.4 \mathrm{eV}$ should also be affiliated with Fe-N. ${ }^{29}$ Different nitrogen functionalities doped into graphitic carbon matrix is beneficial for ORR catalysis. Previous studies have reported that pyrrolic $\mathrm{N}$ play a role in reducing $\mathrm{O}_{2}$ to $\mathrm{H}_{2} \mathrm{O}_{2}$, while pyridinic $\mathrm{N}$ can improve the onset potential and play a role in reducing $\mathrm{H}_{2} \mathrm{O}_{2}$ to $\mathrm{H}_{2} \mathrm{O}$ and graphitic $\mathrm{N}$ contributes to the improvement of limiting diffusion current. Meanwhile, the pyridinic $\mathrm{N}$ is regarded as the main site for binding the transition metal ions, and the Fe-N dominates a four-electron transfer pathway for ORR. ${ }^{16,30}$ The Fe $2 p$ profile can be reclassified into two components: $\mathrm{Fe} 2 \mathrm{p}_{1 / 2}$ and $\mathrm{Fe} 2 \mathrm{p}_{3 / 2}$, corresponding to $723.6 \mathrm{eV}$ and $710 \mathrm{eV}$, respectively (Fig. 3d). ${ }^{31}$ No peaks detected between $710 \mathrm{eV}$ to $724 \mathrm{eV}$ proved that the purity of the $\mathrm{Fe}_{3} \mathrm{O}_{4}$ sample without $\gamma$-Fe2O3. ${ }^{32} \mathrm{Fe} 2 \mathrm{p}$ peak at $711 \mathrm{eV}$ was contributed to coordinating to nitrogen according to previous report. ${ }^{33}$ 
Considering above, the distinctive structure and composition of $\mathrm{Fe}_{3} \mathrm{O}_{4} @ \mathrm{~N}-\mathrm{mC}$ catalyst, which in detail is nitrogen-doped mesoporous graphitic carbon matrix shell embedded with $\mathrm{Fe}_{3} \mathrm{O}_{4}$ nanoparticles core, could to a large extent improve ORR activity. $\mathrm{Fe}_{3} \mathrm{O}_{4}$ nanoparticles core could also activate graphitic carbon layers and coordinate with nitrogen to form well-supplied available active sites and fast the transfer of ORRrelevant species, and afterward enhance the ORR electrocatalysis.

\section{Electrocatalytic ORR activity of $\mathrm{Fe}_{3} \mathrm{O}_{4} @ \mathrm{~N}-\mathrm{mC}$}

The electrocatalytic activity of the $\mathrm{Fe}_{3} \mathrm{O}_{4} @ \mathrm{~N}-\mathrm{mC}$ toward ORR was assessed via rotating disk electrode $(\mathrm{RDE})$ experiments compared with commercial catalyst $(\mathrm{Pt} / \mathrm{C}$, $20 \mathrm{wt} \%$ ) (Fig. 4 and Fig. S3). When the rotating speed is $1600 \mathrm{rpm}$, polarization curves of $\mathrm{Fe}_{3} \mathrm{O}_{4} @ \mathrm{~N}-\mathrm{mC}$ showed a slightly lower onset potential (0.302 V vs. Ag/AgCl) but higher limiting current density $\left(3.54 \mathrm{~mA} \mathrm{~cm}^{-2}\right)$ than those observed in $\mathrm{Pt} / \mathrm{C}(0.34 \mathrm{~V}$ and $2.99 \mathrm{~mA} \mathrm{~cm}^{-2}$ ) (Fig. 4b). The ORR kinetics calculated based on Koutecky-Levich (KL) equation demonstrated the rotation-dependent currents at different potential values. The linear K-L plots of $\mathrm{Fe}_{3} \mathrm{O}_{4} @ \mathrm{~N}-\mathrm{mC}$ electrodes with good parallelism implied firstorder reaction kinetics of oxygen concentration. The electron transfer number of $\mathrm{Fe}_{3} \mathrm{O}_{4} @ \mathrm{~N}-\mathrm{mC}(\mathrm{n}=3.86)$ was higher than that of $\mathrm{Pt} / \mathrm{C}$ catalyst $(\mathrm{n}=3.77)$ (Fig. 4c and Fig. S4). The results indicate that the ORR in $\mathrm{Fe}_{3} \mathrm{O}_{4} @ \mathrm{~N}-\mathrm{mC}$ dominantly followed the fourelectron pathway reaction. 

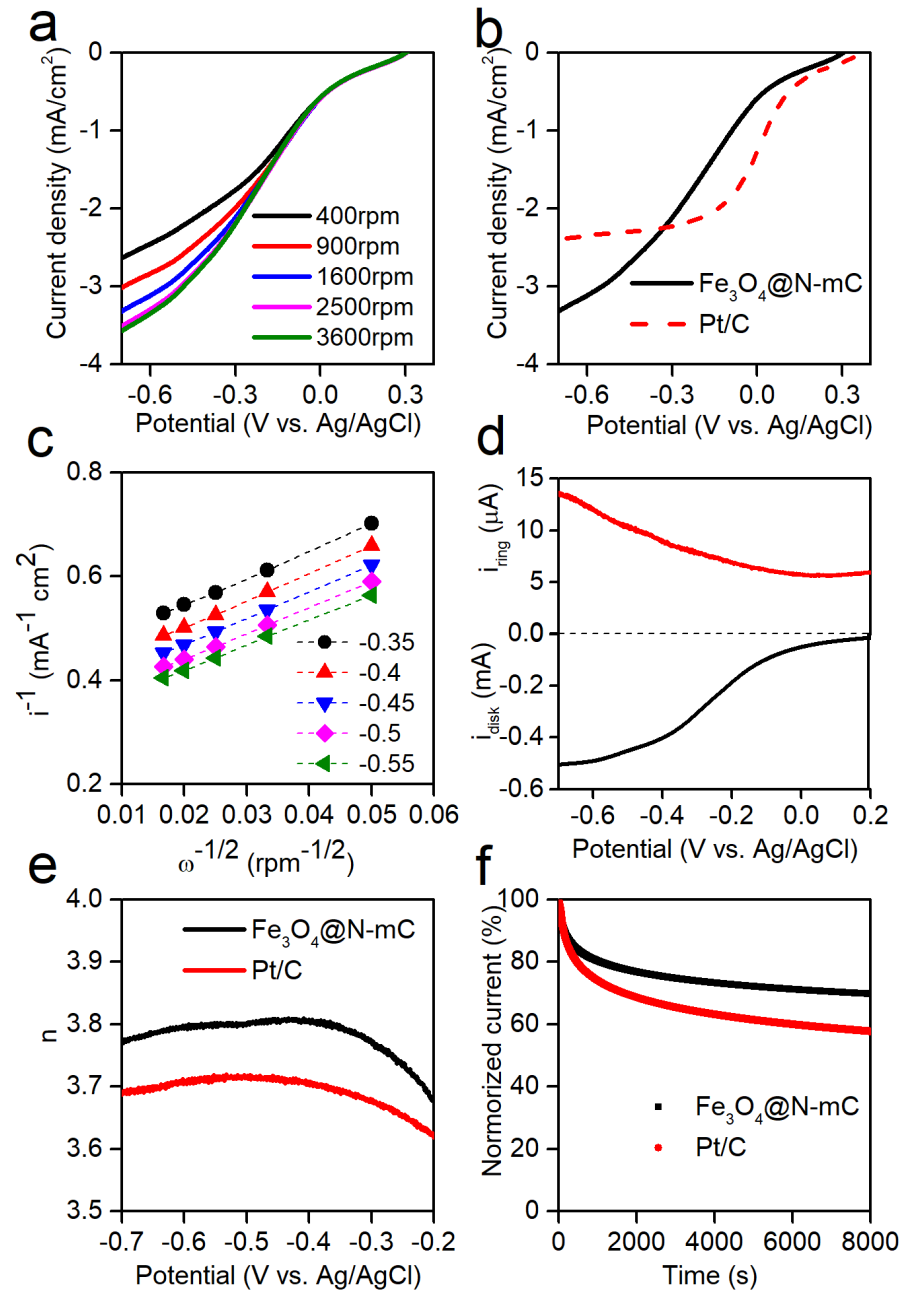

Fig. 4 Polarization curves of $\mathrm{Fe}_{3} \mathrm{O}_{4} @ \mathrm{~N}-\mathrm{mC}$ recorded by $\mathrm{RDE}$ at various rotating speed (a), Linear scan voltammetry of $\mathrm{Fe}_{3} \mathrm{O}_{4} @ \mathrm{~N}-\mathrm{mC}$ and $\mathrm{Pt} / \mathrm{C}$ with a rotating speed of 1600 rpm (b), the Koutecky-Levich plots of $\mathrm{Fe}_{3} \mathrm{O}_{4} @ \mathrm{~N}-\mathrm{mC}$ at different potential (c), polarization curves of $\mathrm{Fe}_{3} \mathrm{O}_{4} @ \mathrm{~N}-\mathrm{mC}$ recorded by RRDE with a rotating speed of 1600 rpm (d), electron transfer number (n) of $\mathrm{Fe}_{3} \mathrm{O}_{4} @ \mathrm{~N}-\mathrm{mC}$ and $\mathrm{Pt} / \mathrm{C}(\mathrm{e})$, and the stability of the $\mathrm{Fe}_{3} \mathrm{O}_{4} @ \mathrm{~N}-\mathrm{mC}$ and $\mathrm{Pt} / \mathrm{C}$ with a constant potential of $-0.4 \mathrm{~V}$. The RDE and RRDE tests were both conducted in PBS $(50 \mathrm{mM})$ saturated with oxygen at room temperature. For further insight into the selectivity of ORR pathway for $\mathrm{Fe}_{3} \mathrm{O}_{4} @ \mathrm{~N}-\mathrm{mC}$, the RRDE technique was used to monitor the electron transfer number by detecting the disk and 
ring current of $\mathrm{Fe}_{3} \mathrm{O}_{4} @ \mathrm{~N}-\mathrm{mC}$ at a constant rotating speed of 1600 rpm (Fig. 4d). The measured $\mathrm{H}_{2} \mathrm{O}_{2}$ yield of $\mathrm{Fe}_{3} \mathrm{O}_{4} @ \mathrm{~N}-\mathrm{mC}$ varied strongly (3.4-16.8\%) under different measured potentials, which was lower than that of $\mathrm{Pt} / \mathrm{C}$ at the potential range of -0.2 to $-0.7 \mathrm{~V}$ (Fig. S5). Based on the ring and disk currents results, the calculated electron transfer numbers for $\mathrm{Fe}_{3} \mathrm{O}_{4} @ \mathrm{~N}-\mathrm{mC}(3.67-3.81)$ were consistent with the values calculated by K-L equation, which were higher than that of $\mathrm{Pt} / \mathrm{C}$ cathode (3.62-3.72) (Fig. 4e). These results indicated that four-electron pathway is dominant in the ORR procedure of $\mathrm{Fe}_{3} \mathrm{O}_{4} @ \mathrm{~N}-\mathrm{mC}$. The superior ORR might be strongly associated with its mesoporous structures, and uniformly dispersion of nitrogen and metal coordinated metal in graphite carbon matrix. ${ }^{13}$ Moreover, as revealed by the RRDE experiments, $\mathrm{Fe}_{3} \mathrm{O}_{4} @ \mathrm{~N}-\mathrm{mC}$ shows superior ORR catalytic activity to that of $\mathrm{Pt} / \mathrm{C}$, implying it is a promising alternative non-precious metal catalyst for ORR.

The durability of the obtained $\mathrm{Fe}_{3} \mathrm{O}_{4} @ \mathrm{~N}-\mathrm{mC}$ catalyst was compared to commercial $\mathrm{Pt} / \mathrm{C}$ catalyst via chronoamperometric tests, which was performed in 50mM PBS saturated with oxygen and applied with the constant potential of $-0.4 \mathrm{~V}$ (Fig. 4f). After $8000 \mathrm{~s}$ testing, the current-time $(\mathrm{i}-\mathrm{t})$ chronoamperometric response showed that $\mathrm{Fe}_{3} \mathrm{O}_{4} @ \mathrm{~N}-\mathrm{mC}$ revealed a slow attenuation with relative higher current retention (70\%) than $\mathrm{Pt} / \mathrm{C}(58 \%)$, which demonstrated higher long-term stability of $\mathrm{Fe}_{3} \mathrm{O}_{4} @ \mathrm{~N}-\mathrm{mC}$ in neutral electrolyte. Numerous active sites dispersed in the mesoporous carbon matrix of $\mathrm{Fe}_{3} \mathrm{O}_{4} @ \mathrm{~N}-\mathrm{mC}$ may prevent the iron and iron related active sites migration and aggregation, and thus, might be contribute to the electrochemical durability. Additionally, even if the outer active sites of $\mathrm{Fe}_{3} \mathrm{O}_{4} @ \mathrm{~N}-\mathrm{mC}$ catalysts were destroyed 
over time in the durability tests, the inner active sites can also expose and access to the electrochemical reaction interface through mesoporous channels to support the ORR durability.

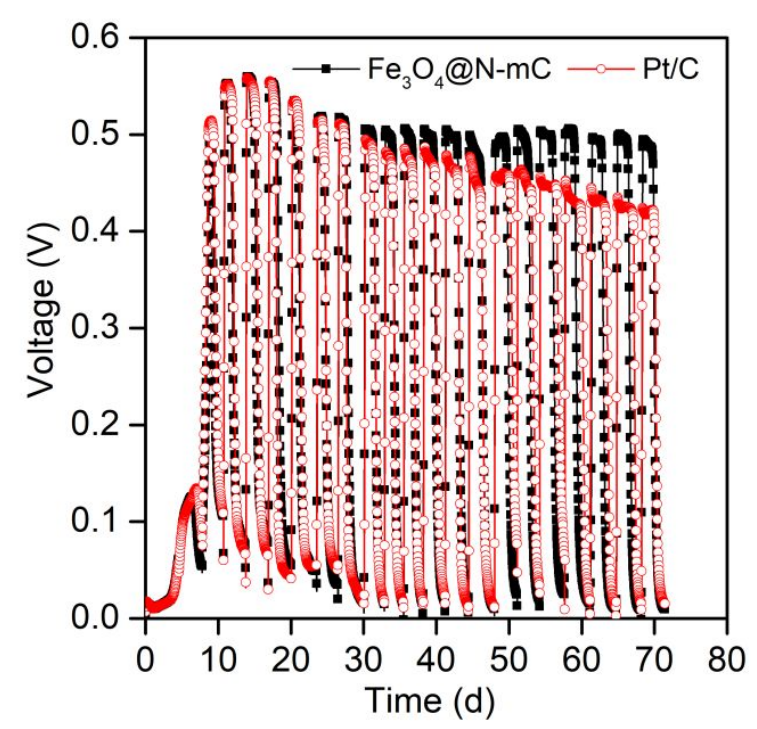

Fig. 5 Voltage production of MFCs with the cathode of $\mathrm{Fe}_{3} \mathrm{O}_{4} @ \mathrm{~N}-\mathrm{mC}$ or $\mathrm{Pt} / \mathrm{C}$ at external resistance of $1000 \Omega$.

\section{Performance of MFC supplied with $\mathrm{Fe}_{3} \mathrm{O}_{4} @ \mathrm{~N}$-mC cathode}

In order to test the feasibility of $\mathrm{Fe}_{3} \mathrm{O}_{4} @ \mathrm{~N}-\mathrm{mC}$ as the cathode catalyst of MFC, aircathode single-chamber MFCs were set up. The performance of MFCs with $\mathrm{Fe}_{3} \mathrm{O}_{4} @ \mathrm{~N}$ $\mathrm{mC}$ as the cathode catalyst $\left(\mathrm{Fe}_{3} \mathrm{O}_{4} @ \mathrm{~N}-\mathrm{mC}-\mathrm{MFC}\right)$ was compared with MFCs with $\mathrm{Pt} / \mathrm{C}$ as the cathode catalyst (Pt/C-MFC). The LSV scan test for cathodes showed that $\mathrm{Fe}_{3} \mathrm{O}_{4} @ \mathrm{~N}-\mathrm{mC}$ cathodes had higher current density $\left(10.94 \mathrm{~A} \mathrm{~m}^{-2}\right)$ than that of $\mathrm{Pt} / \mathrm{C}$ cathode (10.07 $\left.\mathrm{A} \mathrm{m}^{-2}\right)$, suggesting the distinguished ORR catalytic activity of $\mathrm{Fe}_{3} \mathrm{O}_{4} @ \mathrm{~N}-\mathrm{mC}$. The results were in good agreement with that obtained by RDE (Fig. S6).

The reactors were operated for 21 cycles in 72 days. The output voltages of $\mathrm{Fe}_{3} \mathrm{O}_{4} @ \mathrm{~N}$ - 
mC-MFC were similar with that of Pt/C-MFC in the first 6 cycles possessing the same highest output voltage of $560 \mathrm{mV}$, however, it turned to be higher than that of $\mathrm{Pt} / \mathrm{C}$ MFC at the later cycles (Fig. 5). Significantly, the voltage value decreased slowly to $496 \mathrm{mV}$ for $\mathrm{Fe}_{3} \mathrm{O}_{4} @ \mathrm{~N}-\mathrm{mC}-\mathrm{MFC}$, whereas it was decreasing to $420 \mathrm{mV}$ for Pt/C-MFC. Based on the above, we can draw the conclusion that MFCs using $\mathrm{Fe}_{3} \mathrm{O}_{4} @ \mathrm{~N}-\mathrm{mC}$ as cathodic catalysts performed better and more stable than Pt/C-based MFC.
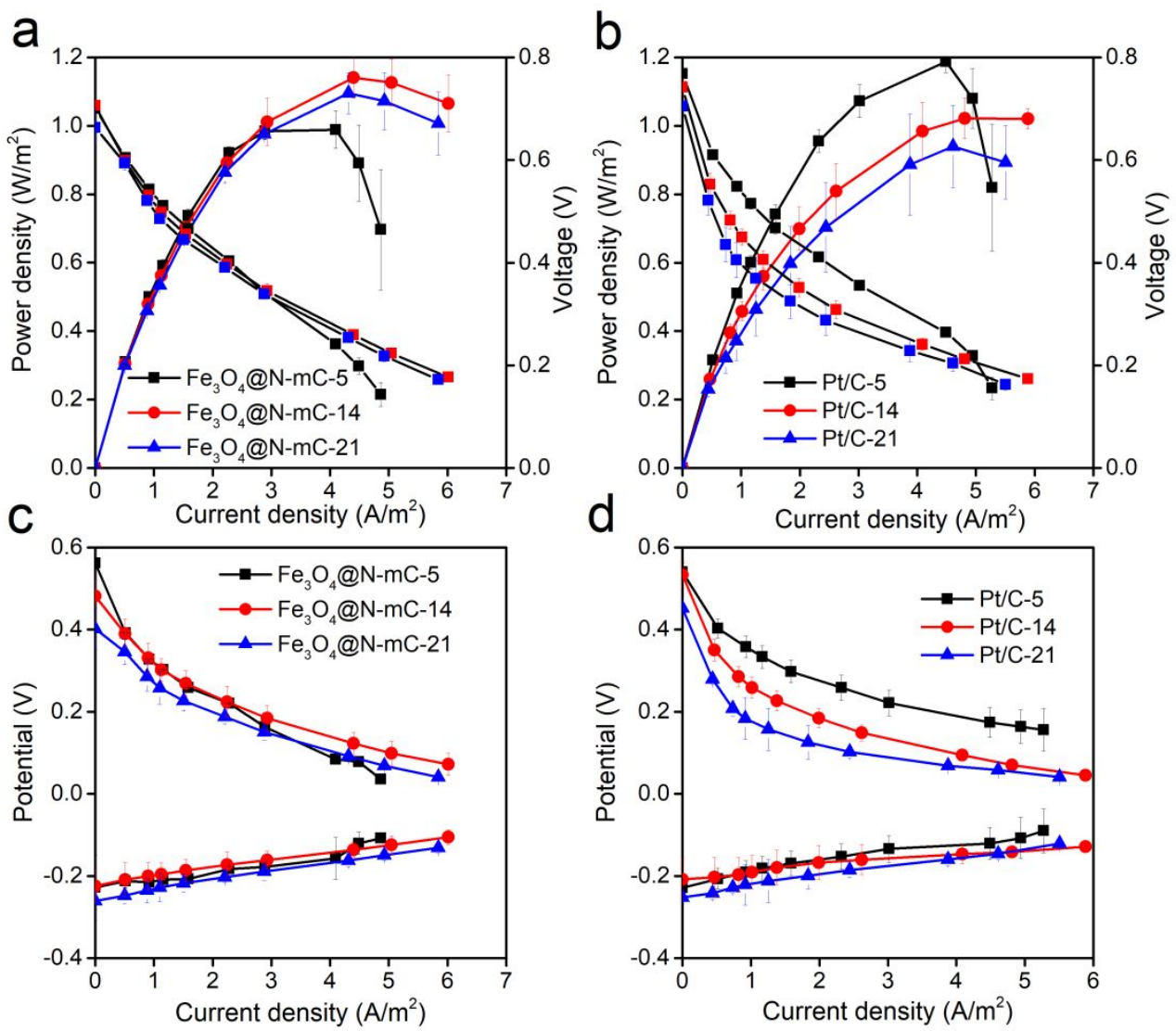

Fig. 6 Power, voltage, and the corresponding anode and cathode potentials of MFCs with the cathode catalysts of $\mathrm{Fe}_{3} \mathrm{O}_{4} @ \mathrm{~N}-\mathrm{mC}$ and $\mathrm{Pt} / \mathrm{C}$ at the 5th cycle, 14th cycle, and 21th cycle.

The power output and polarization curves were both performed after operating for 5 cycles, 14 cycles, and 21 cycles (Fig. 6). The power density of MFCs with $\mathrm{Fe}_{3} \mathrm{O}_{4} @ \mathrm{~N}$ $\mathrm{mC}$ were $989 \mathrm{~mW} \mathrm{~m}^{-2}$ after 5 cycle operation, which were slightly lower than that with 
$\mathrm{Pt} / \mathrm{C}$ cathodes $\left(1187 \mathrm{~mW} \mathrm{~m}^{-2}\right)$. More importantly, after 14 cycles operation, the power density of $\mathrm{Fe}_{3} \mathrm{O}_{4} @ \mathrm{~N}-\mathrm{mC}-\mathrm{MFC}$ increased by $15.4 \%$ to $1141 \mathrm{mV} \mathrm{m}{ }^{-2}$, which was higher than that detected in Pt/C-MFC (1022 $\left.\mathrm{mV} \mathrm{m}^{-2}\right)$. Furthermore, after 21 cycles operation, the power density of all MFCs showed downtrend with 1095 mW m² for $\mathrm{Fe}_{3} \mathrm{O}_{4} @ \mathrm{~N}$ mC-MFC and $940 \mathrm{~mW} \mathrm{~m}^{-2}$ for Pt/C-MFC. According to polarization curves, all MFCs showed low potential at high current density region in initial operation stage, implying their high diffusion resistance. In the case of $\mathrm{Fe}_{3} \mathrm{O}_{4} @ \mathrm{~N}-\mathrm{mC}-\mathrm{MFCs}$, the potential at high current density region increased in fourteenth cycle, which led to the increase in power density. Thereafter, it had hardly any change at all after 21 cycle operation compared to $\mathrm{Pt} / \mathrm{C}-\mathrm{MFC}$. It is obvious that $\mathrm{Pt} / \mathrm{C}-\mathrm{MFC}$ had much lower potential at medium current density region after long time operation, which illustrated that the activation resistance of $\mathrm{Pt} / \mathrm{C}-\mathrm{MFC}$ increased with the running time. The increase of activation resistance might cause by the biofouling on catalysts surface and gradually decreased ORR activity, which also could lead to the lower power density of Pt/C-MFC. Furthermore, the anode and cathode potentials versus current density also showed the unanimous anode potential and diverse cathode potential. The cathode potential decreased followed the same trend of polarization curves, which demonstrated that the differences in power generation were ascribed to the different ORR properties of the cathodes. Moreover, the coulombic efficiency was also detected to analyze water-processing ability of MFCs. With the similar COD removal rate, the $\mathrm{Fe}_{3} \mathrm{O}_{4} @ \mathrm{~N}-\mathrm{mC}-\mathrm{MFCs}$ reached to higher coulombic efficiency (26\%) compared to that of Pt/C-MFCs (21.7\%) (Fig. S7). 
These results demonstrate that $\mathrm{Fe}_{3} \mathrm{O}_{4} @ \mathrm{~N}-\mathrm{mC}$ can be a favorable alternative for commercial Pt/C catalyst in MFC. The power density obtained in $\mathrm{Fe}_{3} \mathrm{O}_{4} @ \mathrm{~N}-\mathrm{mC}-\mathrm{MFCs}$ $\left(1141 \mathrm{mWm}^{-2}\right.$ or $\left.36.7 \mathrm{~W} / \mathrm{m}^{3}\right)$ was also higher than that of works previously reported (Table S1). For instance, the power density was $730 \mathrm{~mW} \mathrm{~m} \mathrm{~m}^{-2}$ for $\mathrm{Fe}_{3} \mathrm{O}_{4} @ \mathrm{~N}-\mathrm{mC}$ with non-nanometer $\mathrm{Fe}_{3} \mathrm{O}_{4}$ core, which we reported previously, ${ }^{15} 12.54 \mathrm{~W} / \mathrm{m}^{3}$ for polyaniline and iron-based catalysts $\left(\mathrm{PANI}-\mathrm{Fe}_{900}\right),{ }^{34} 399 \mathrm{mWm}^{-2}$ for Co-N-doped carbon $(\mathrm{Co}-\mathrm{N}-\mathrm{C}),{ }^{35}$ and $745 \mathrm{mWm}^{-2}$ for $\mathrm{N} / \mathrm{Fe}$ co-doped carbon $(\mathrm{N} / \mathrm{Fe}-\mathrm{C}) .{ }^{36}$ The outstanding ORR activity and better durability of $\mathrm{Fe}_{3} \mathrm{O}_{4} @ \mathrm{~N}-\mathrm{mC}$ as MFC cathode was inevitably ascribed to the its well-defined structure features: (1) the ordered mesoporous structure results in more accessible active sites to promote proton and oxygen transportation and adsorption, suppress the agglomeration of the $\mathrm{Fe}_{3} \mathrm{O}_{4}$ nanoparticles, and thus, speed up the mass exchange of ORR; ${ }^{14}$ (2) numerous nitrogen functional groups distributed in carbon matrix have considered to facilitate oxygen reduction, and on the basis of that the coordination of $\mathrm{N}$ and $\mathrm{Fe}$ can offer more active sites favorable to ORR; 9,16 (3) the introduction of $\mathrm{Fe}_{3} \mathrm{O}_{4}$ catalyze the carbonization of PANI to provide more order graphite carbon, which with high conductivity to enhance the electron transfer; ${ }^{17,37}(4)$ the core-shell structure of $\mathrm{Fe}_{3} \mathrm{O}_{4} @ \mathrm{~N}-\mathrm{mC}$ can prevent acid-leaching, oxidation and aggregation of $\mathrm{Fe}_{3} \mathrm{O}_{4}$ to achieve the high durability of catalysts. ${ }^{38}$ In conclusion, a mesoporous $\mathrm{Fe}_{3} \mathrm{O}_{4} @ \mathrm{~N}-\mathrm{mC}$ catalyst was developed by employing SDS and $\mathrm{P} 123$ soft template agents. The $\mathrm{Fe}_{3} \mathrm{O}_{4} @ \mathrm{~N}-\mathrm{mC}$ can considerably lessen the expense, while exhibited higher ORR activity (limiting current density, $3.54 \mathrm{~mA} \mathrm{~cm}{ }^{-2}$ ), higher selectivity (electron transfer number, 3.66-3.94), and better long-term electrochemical 
stability in neutral solutions in comparison with the commercial $\mathrm{Pt} / \mathrm{C}$ catalysts. The superior activity and durability toward the ORR of $\mathrm{Fe}_{3} \mathrm{O}_{4} @ \mathrm{~N}-\mathrm{mC}$ was attributed to its well-defined mesoporous core-shell structure and numerous nitrogen functional groups dispersed in the carbon matrix. When it was applied in MFCs as cathodic catalysts, the $\mathrm{Fe}_{3} \mathrm{O}_{4} @ \mathrm{~N}-\mathrm{mC}-\mathrm{MFC}$ exceeded the $\mathrm{Pt} / \mathrm{C}-\mathrm{MFC}$ in durability performance, power production, and coulombic efficiency. Results demonstrate that the nonprecious metal catalysts had great potential efficient catalyst to replace commercial precious catalysts such as Pt.

\section{ASSOCIATED CONTENT}

\section{Supporting Information}

The supporting information is available free of charge on ACS publication website at http://pubs.acs.org.

Characterization methods; Comparison of power density between MFCs with different nonprecious metal catalysts (NPMCs); Nitrogen adsorption-desorption isotherms and Raman spectras of $\mathrm{Fe}_{3} \mathrm{O}_{4} @ \mathrm{~N}-\mathrm{mC}$ catalyst; RDE polarization curves and KouteckyLevich plots of Pt/C; Peroxide species detected on ring electrode of $\mathrm{Fe}_{3} \mathrm{O}_{4} @ \mathrm{~N}-\mathrm{mC}$ and Pt/C; The LSV scan, COD removal rate, and Coulombic efficiency of MFC cathodes with $\mathrm{Fe}_{3} \mathrm{O}_{4} @ \mathrm{~N}-\mathrm{mC}$ and $\mathrm{Pt} / \mathrm{C}$ catalysts;

\section{Acknowledgements}

Authors would like to thank the financial support from National Natural Science Foundation of China (No. 31870114), the Science Fund for Distinguished Young 
Scholars of Heilongjiang Province (Grant No. JC201407), and the State Key Laboratory of Urban Water Resources, and Environment (Harbin Institute of Technology) (No. 2019DX02). H. Z. also appreciates the China Scholarship Council (CSC).

\section{Declarations of interest}

None

\section{References}

(1) Logan, B.E.; Rabaey, K. Conversion of wastes into bioelectricity and chemicals by using microbial electrochemical technologies. Science 2012, 337, 686-690.

(2) Rabaey, K.; Verstraete, W. Microbial fuel cells: novel biotechnology for energy generation. Trends Biotechnol. 2015, 23, 291-298.

(3) Sonawane, J.M.; Yadav, A.; Ghosh, P.C.; Adeloju, S.B. Recent advances in the development and utilization of modern anode materials for high performance microbial fuel cells. Biosens. Bioelectron. 2017, 90, 558-576.

(4) Logan, B.E.; Hamelers, B.; Rozendal, R.; Schröder, U.; Keller, J.; Freguia, S.; Aelterman, P.; Verstraete, W.; Rabaey, K. Microbial fuel cells methodology and technology. Environ. Sci. Technol. 2006, 40, 5181-5192.

(5) Thorseth, M.A.; Tornow, C.E.; Tse, E.C.M.; Gewirth, A.A.; Cu complexes that catalyze the oxygen reduction reaction. Coordin. Chem. Rev. 2013, 257, 130-139.

(6) Oh, S.; Min, B.; Logan, B.E.; Cathode performance as a factor in electricity generation in microbial fuel cells. Environ. Sci. Technol. 2004, 38, 4900. 
(7) Hebié, S.; Bayo-Bangoura, M.; Bayo, K.; Servat, K.; Morais, C.; Napporn, T.W.; Kokoh, K.B. Electrocatalytic activity of carbon-supported metallophthalocyanine catalysts toward oxygen reduction reaction in alkaline solution. J. Solid State Electr. 2016, 20, 1-12.

(8) Ferrero, G.A.; Preuss, K.; Marinovic, A.; Jorge, A.B.; Mansor, N.; Brett, D.J.; Fuertes, A.B.; Sevilla, M.; Titirici, M.M. Fe-N-doped carbon capsules with outstanding electrochemical performance and stability for the oxygen reduction reaction in both acid and alkaline conditions. ACS Nano 2016, 10, 5922-5932.

(9) Wu, G.; More, K.L.; Johnston, C.M.; Zelenay, P. High-performance electrocatalysts for oxygen reduction derived from polyaniline, iron, and cobalt. Science 2011, 332, 443-447.

(10) Gong, K.; Du, F.; Xia, Z.; Durstock, M.; Dai, L. Nitrogen-doped carbon nanotube arrays with high electrocatalytic activity for oxygen reduction. Science 2009, 323, 760. (11) Wang, D.; Su, D. Heterogeneous nanocarbon materials for oxygen reduction reaction. Energy Environ. Sci. 2014, 7, 576.

(12) Geng, D.; Chen, Y.; Chen, Y.; Li, Y.; Li, R.; Sun, X.; Ye, S.; Knights, S. High oxygen-reduction activity and durability of nitrogen-doped graphene. Energy Environ. Sci. 2011, 4, 760-764.

(13) Liang, H.W.; Wei, W.; Wu, Z.S.; Feng, X.; Mullen, K. Mesoporous metalnitrogen-doped carbon electrocatalysts for highly efficient oxygen reduction reaction. J. Am. Chem. Soc. 2013, 135, 16002-16005.

(14) Xiao, M.; Zhu, J.; Feng, L.; Liu, C.; Xing, W. Meso/macroporous nitrogen-doped 
carbon architectures with iron carbide encapsulated in graphitic layers as an efficient and robust catalyst for the oxygen reduction reaction in both acidic and alkaline solutions. Adv. Mater. 2015, 27, 2521-2527.

(15) Zhou, H.; Yang, Y.; You, S.; Liu, B.; Ren, N.; Xing, D. Oxygen reduction reaction activity and the microbial community in response to magnetite coordinating nitrogendoped carbon catalysts in bioelectrochemical systems. Biosens. Bioelectron. 2018, 122 , 113-120.

(16) Artyushkova, K.; Serov, A.; Rojas-Carbonell, S.; Atanassov, P. Chemistry of multitudinous active sites for oxygen reduction reaction in transition metal-nitrogencarbon electrocatalysts. J. Phys. Chem. C 2015, 119, 25917-25928.

(17) Sevilla, M.; Fuertes, A.B. Catalytic graphitization of templated mesoporous carbons. Carbon 2006, 44, 468-474.

(18) Zhou, H.; Liu, B.; Wang, Q.; Sun, J.; Xie, G.; Ren, N.; Ren, Z.J.; Xing, D. Pulse electromagnetic fields enhance extracellular electron transfer in magnetic bioelectrochemical systems. Biotechnol. Biofuels 2017, 10, 238-249.

(19) Zhou, H.; Mei, X.; Liu, B.; Xie, G.; Xing, D. Magnet anode enhances extracellular electron transfer and enrichment of exoelectrogenic bacteria in bioelectrochemical systems. Biotechnol. Biofuels 2019, 12, 133.

(20) Hachani, R.; Lowdell, M.; Birchall, M.; Hervault, A.; Mertz, D.; Begin-Colin, S.; Thanh, N.T. Polyol synthesis, functionalisation, and biocompatibility studies of superparamagnetic iron oxide nanoparticles as potential MRI contrast agents. Nanoscale 2016, 8, 3278-3287. 
(21) Dong, H.; Yu, H.; Wang, X.; Zhou, Q.; Feng, J.; A novel structure of scalable aircathode without Nafion and Pt by rolling activated carbon and PTFE as catalyst layer in microbial fuel cells. Water Res. 2012, 46, 5777-5787.

(22) Jia, J.; Tang, Y.; Liu, B.; Wu, D.; Ren, N.; Xing, D.; Electricity generation from food wastes and microbial community structure in microbial fuel cells. Bioresour.Technol. 2013, 144, 94-99.

(23) Xing, D.; Yu, T.; Mei, X.; Liu, B. Electricity generation of microbial fuel cell with waterproof breathable membrane cathode. J. Power Sources 2015, 300, 491-495.

(24) Lalaurette, E.; Thammannagowda, S.; Mohagheghi, A.; Maness, P.C.; Logan, B.E. Hydrogen production from cellulose in a two-stage process combining fermentation and electrohydrogenesis. Int. J. Hydrog. Energy 2009, 34, 6201-6210.

(25) Sevilla, M.; Sanchís, C.; ValdésSolís, T.; Morallón, E.; Fuertes, A. B. Synthesis of graphitic carbon nanostructures from sawdust and their application as electrocatalyst supports. Phys. Chem. Chem. Phys. 2007, 111, 9749-9756.

(26) Pimenta, M.A.; Dresselhaus, G.; Dresselhaus, M.S.; Cançado, L.G.; Jorio, A.; Saito, R. Studying disorder in graphite-based systems by Raman spectroscopy. Phys. Chem. Chem. Phys. 2007, 9, 1276-1291.

(27) Daems, N.; Sheng, X.; Vankelecom, I.F.J.; Pescarmona, P.P. Metal-free doped carbon materials asmelectrocatalysts for the oxygen reduction reaction. J. Mater. Chem. A 2014, 2, 4085-4110.

(28) Kong, A.; Zhu, X.; Han, Z.; Yu, Y.; Zhang, Y.; Dong, B.; Shan, Y. Ordered hierarchically micro- and mesoporous $\mathrm{Fe}-\mathrm{Nx}$-embedded graphitic architectures as 
efficient electrocatalysts for oxygen reduction reaction. ACS Catal. 2014, 4, 1793-1800. (29) Sarapuu, A.; Kreek, K.; Kisand, K.; Kook, M.; Uibu, M.; Koel, M.; Tammeveski, K. Electrocatalysis of oxygen reduction by iron-containing nitrogen-doped carbon aerogels in alkaline solution. Electrochim. Acta 2017, 230, 81-88.

(30) Lai, L.; Potts, J.R.; Zhan, D.; Wang, L.; Poh, C.K.; Tang, C.; Gong, H.; Shen, Z.; Lin, J.; Ruoff, R.S. Exploration of the active center structure of nitrogen-doped graphene-based catalysts for oxygen reduction reaction. Energy Environ. Sci. 2012, 5, 7936-7942.

(31) Wu, Z.S.; Yang, S.; Sun, Y.; Parvez, K.; Feng, X.; Mullen, K.; 3D nitrogen-doped graphene aerogel-supported $\mathrm{Fe}_{3} \mathrm{O}_{4}$ nanoparticles as efficient electrocatalysts for the oxygen reduction reaction. J. Am. Chem. Soc. 2012, 134, 9082-9085.

(32) Gu, X.; Sun, Z.; Wu, S.; Qi, W.; Wang, H.; Xu, X.; Su, D. Surfactant-free hydrothermal synthesis of sub-10 $\mathrm{nm} \gamma-\mathrm{Fe}_{2} \mathrm{O}_{3}$-polymer porous composites with high catalytic activity for reduction of nitroarenes. Chem. Commun. 2013, 49, 1008810090.

(33) Wu, G.; Chen, Z.; Artyushkova, K.; Garzon, F.H.; Zelenay, P. Polyaniline-derived non-precious catalyst for the polymer electrolyte fuel cell cathode. ECS Trans.2008, $16,159-170$.

(34) Tang, X.; Li, H.; Du, Z.; Ng, H.Y. Polyaniline and iron based catalysts as air cathodes for enhanced oxygen reduction in microbial fuel cells. $R S C A d v . \mathbf{2 0 1 5}, 5$, 79348-79354.

(35) Li, J.C.; Wu, X.T.; Chen, L.J.; Nan, L.; Liu, Z.Q.; Bifunctional MOF-derived Co- 
$\mathrm{N}$-doped carbon electrocatalysts for high-performance zinc-air batteries and MFCs. Energy 2018, 156, 95-102.

(36) Cao, C.; Wei, L.; Su, M.; Wang, G.; Shen, J. Low-cost adsorbent derived and in situ nitrogen/iron co-doped carbon as efficient oxygen reduction catalyst in microbial fuel cells. Bioresour. Technol. 2016, 214, 348-354.

(37) Yang, M.; Yang, D.; Chen, H.; Gao, Y.; Li, H. Nitrogen-doped carbon nanotubes as catalysts for the oxygen reduction reaction in alkaline medium. J. Power Sources 2015, 279, 28-35.

(38) Wang, J.; Wu, H.; Gao, D.; Miao, S.; Wang, G.; Bao, X. High-density iron nanoparticles encapsulated within nitrogen-doped carbon nanoshell as efficient oxygen electrocatalyst for zinc-air battery. Nano Energy 2015, 13, 387-396. 


\section{TOC}

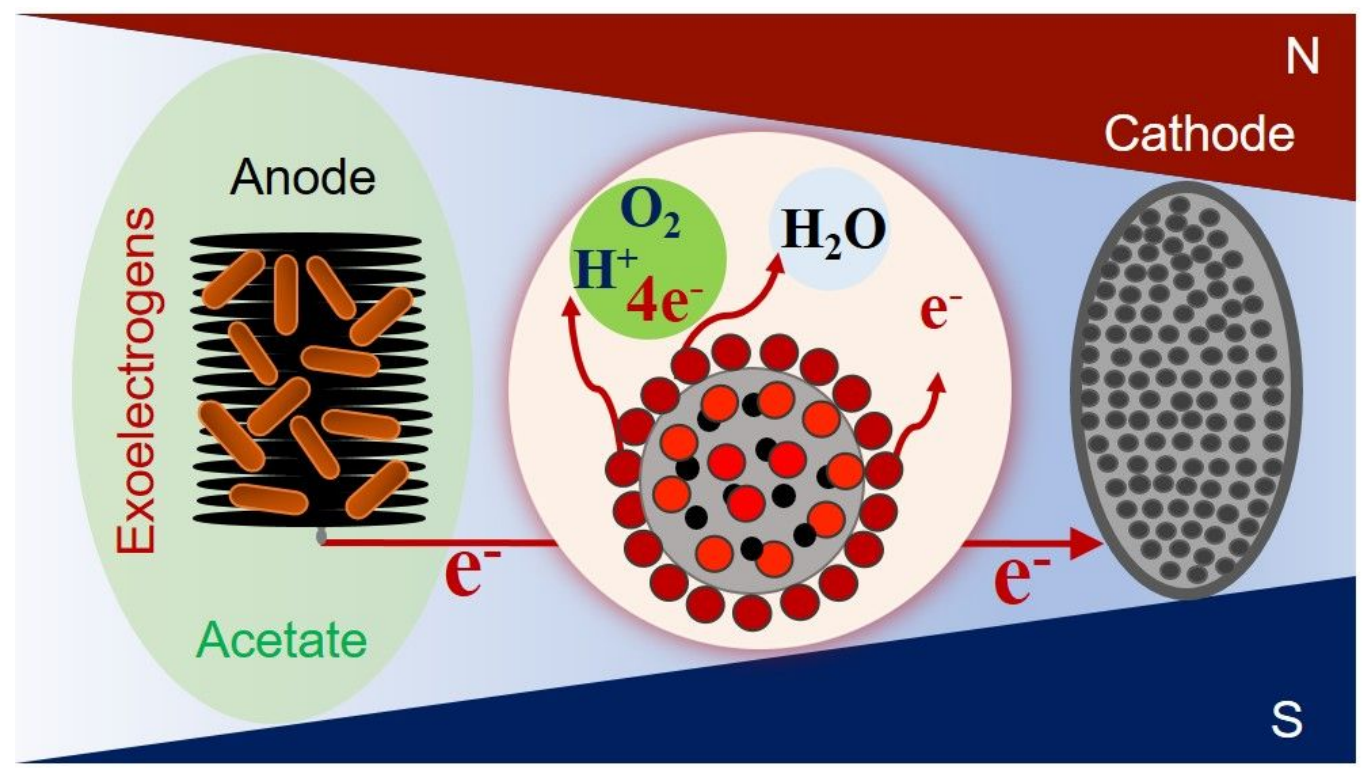

Synopsis : This work focus on exploring the cost-effective cathode catalyst for microbial fuel cells, which is an eco-friendly biotechnology for recovering energy from biodegradable wastes. 


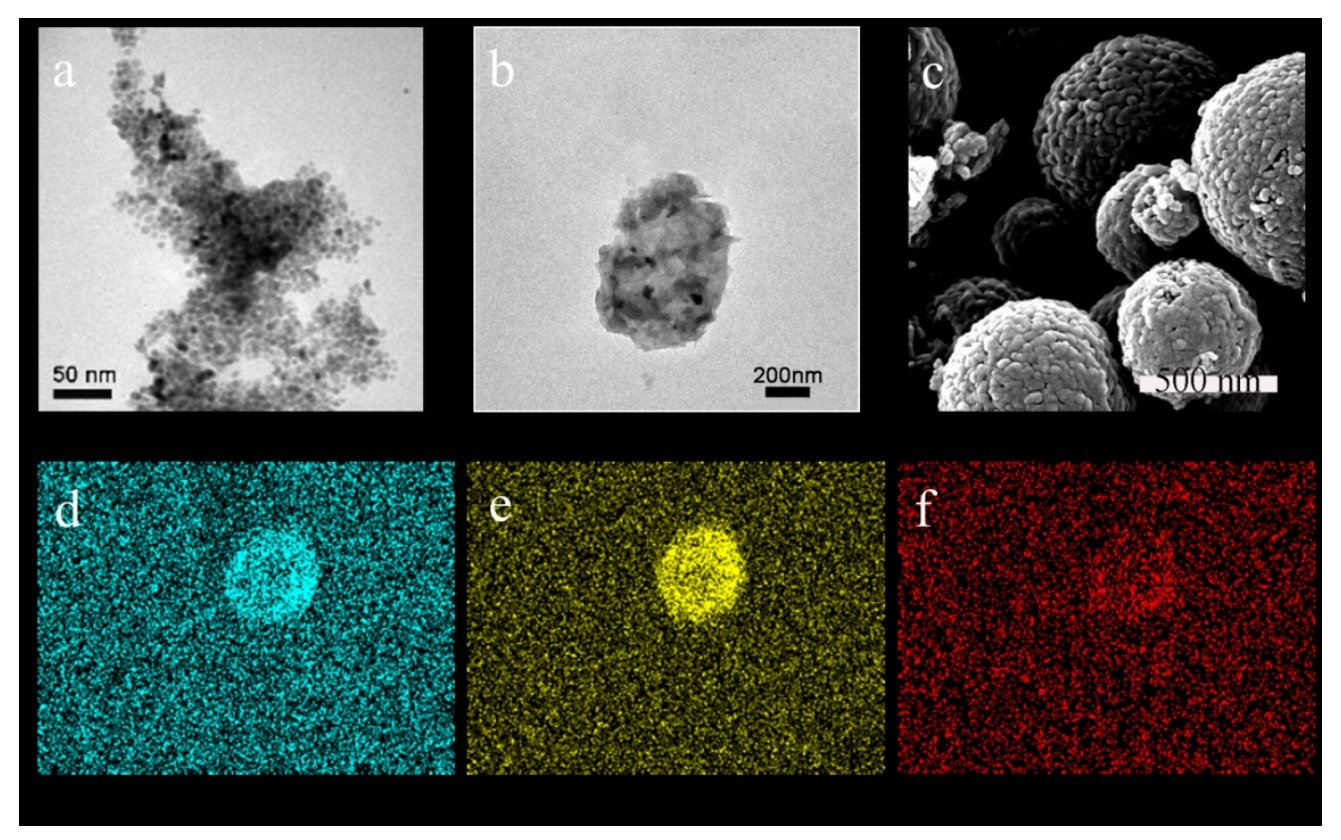

Fig. 1 SEM TEM

$236 \times 147 \mathrm{~mm}(150 \times 150 \mathrm{DPI})$ 


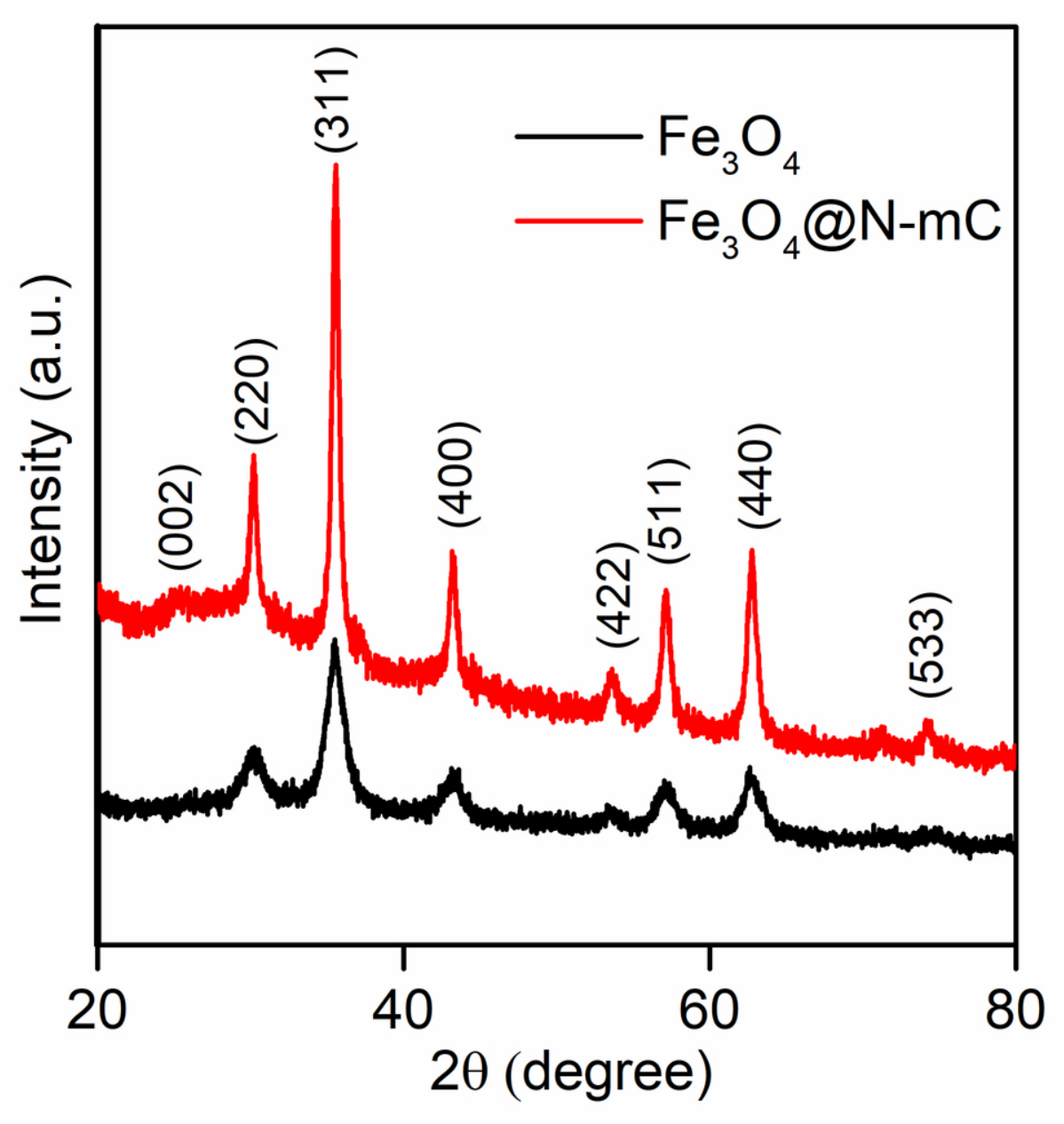

Fig. 2 XRD

$88 \times 87 \mathrm{~mm}(300 \times 300$ DPI) 

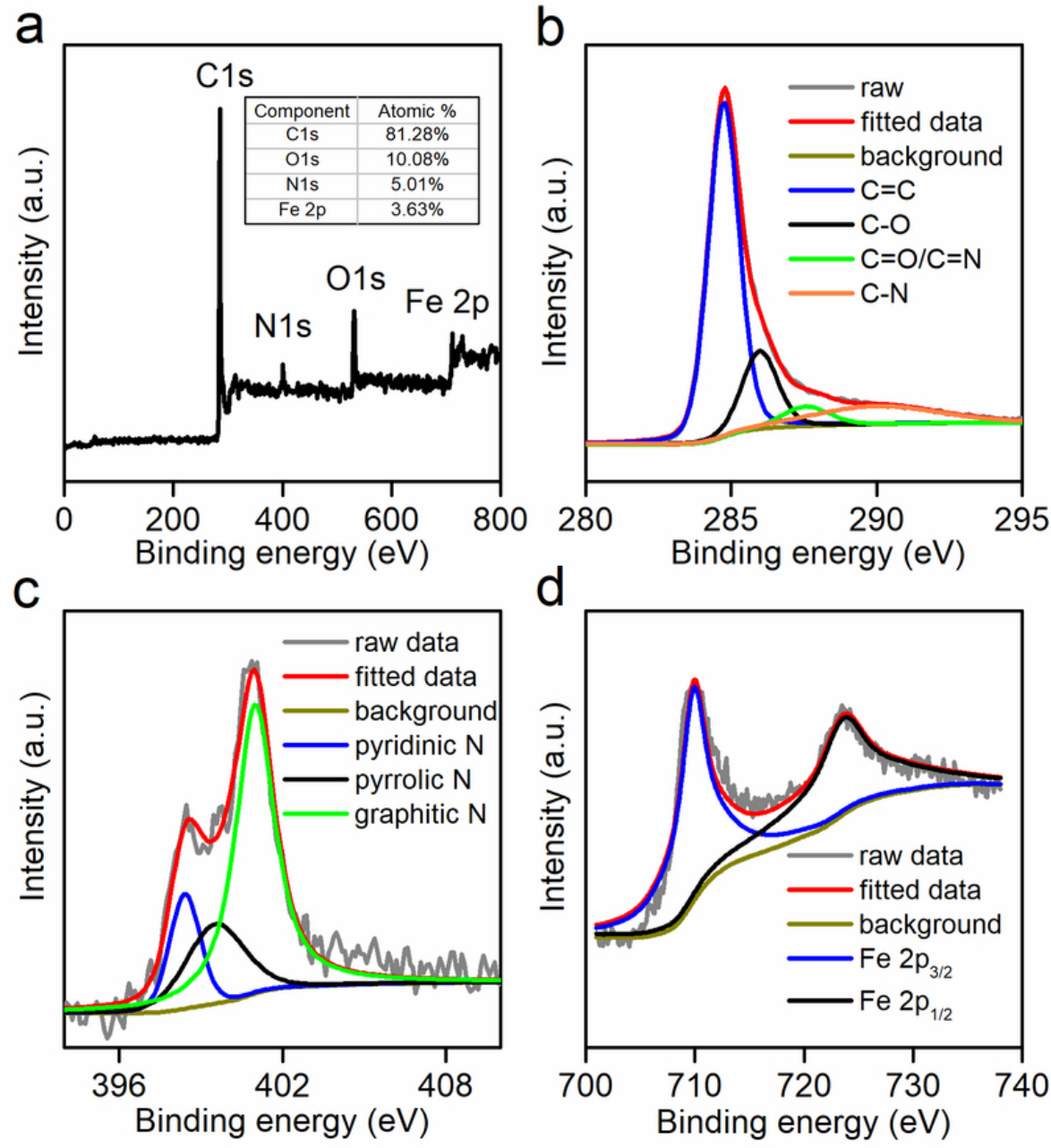

Fig. 3 XPS

$74 \times 78 \mathrm{~mm}(300 \times 300$ DPI $)$ 

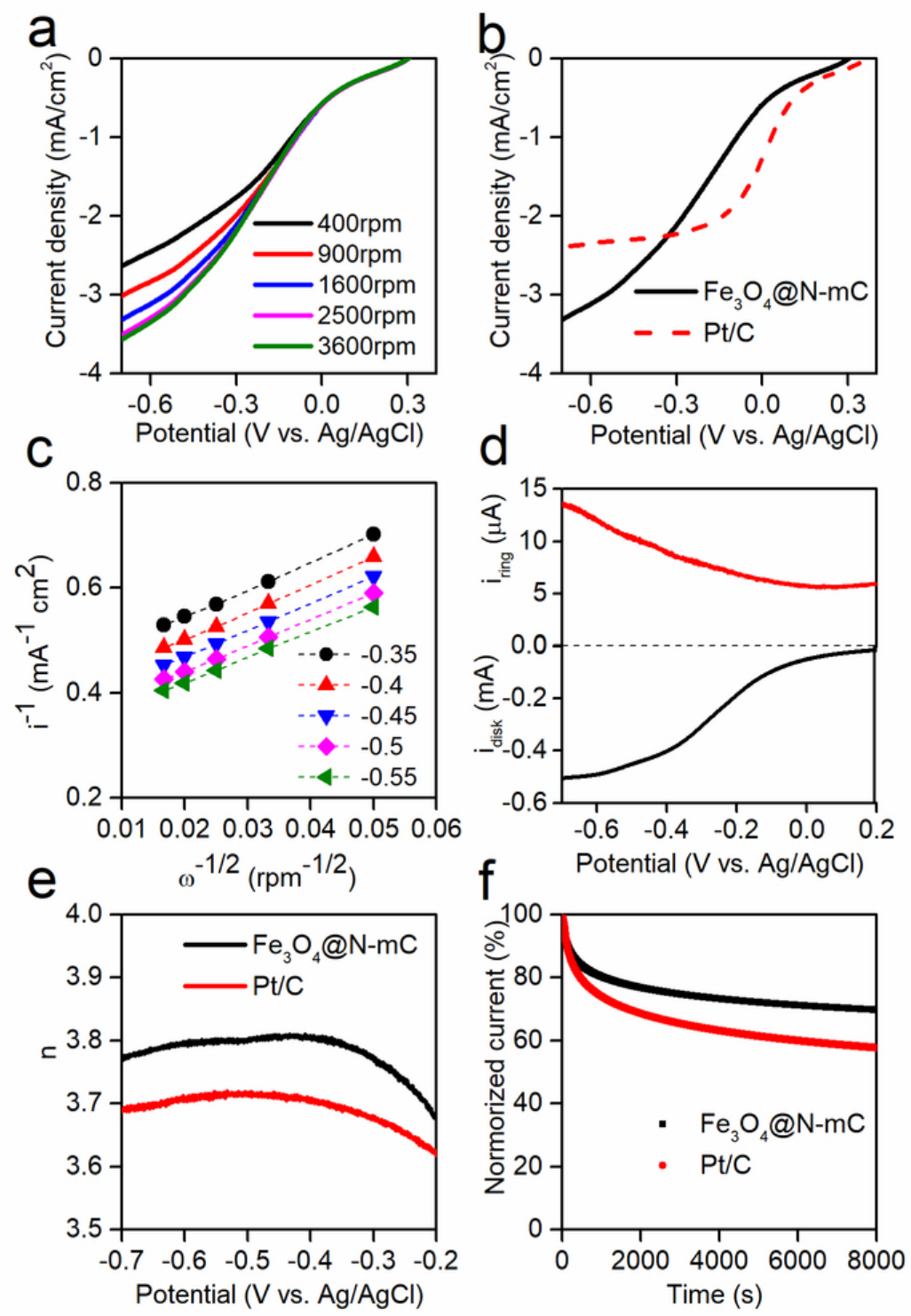

Fig. 4 ORR

$61 \times 87 \mathrm{~mm}(300 \times 300$ DPI $)$ 


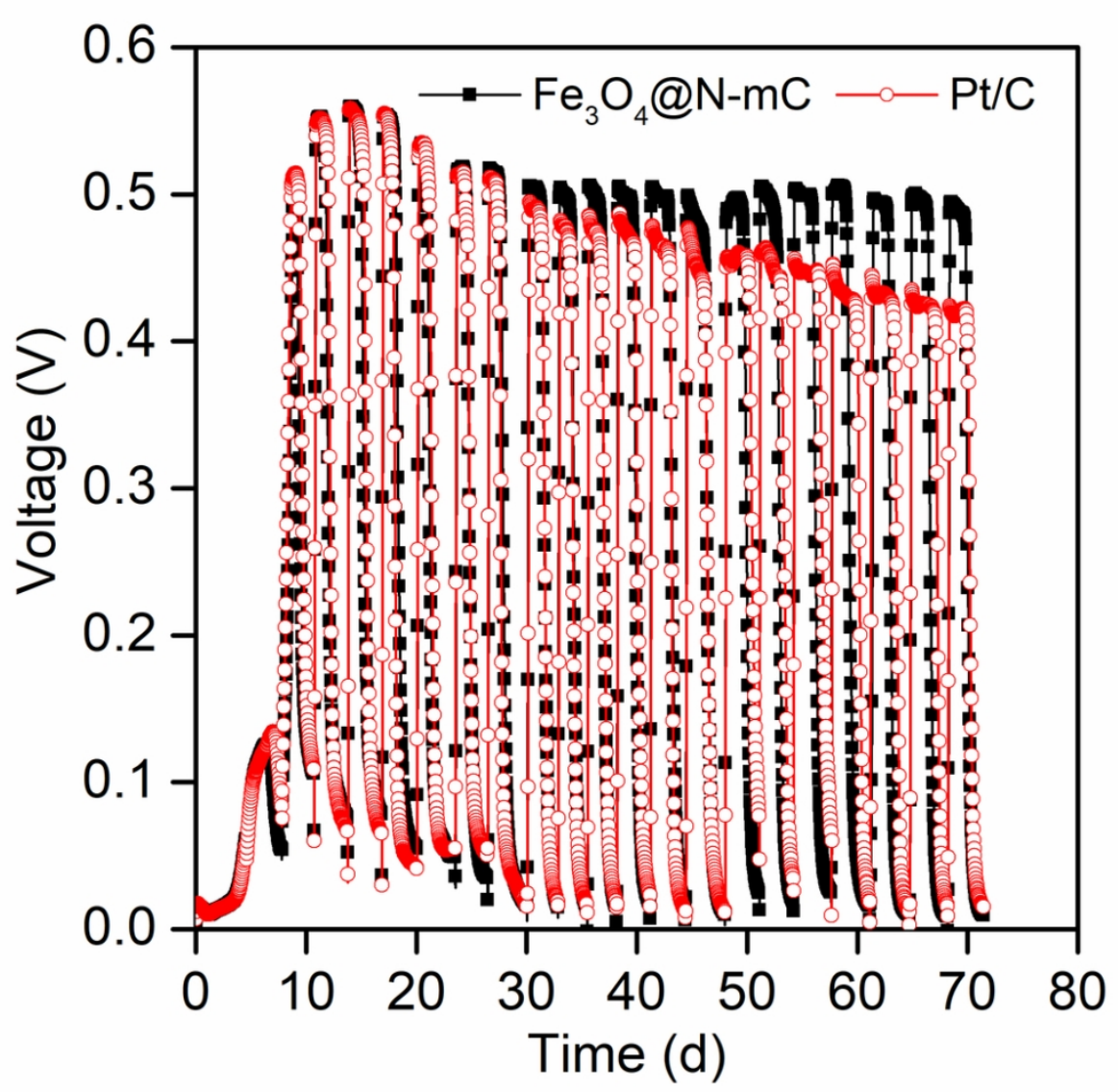

Fig. 5 Output voltage

$99 \times 95 \mathrm{~mm}(300 \times 300$ DPI $)$ 

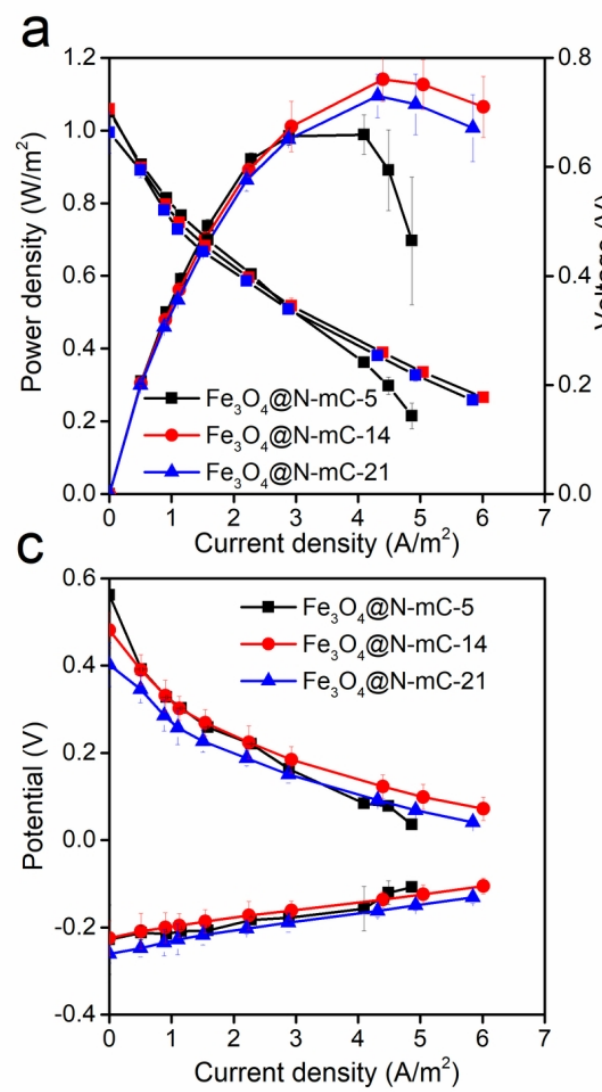

b
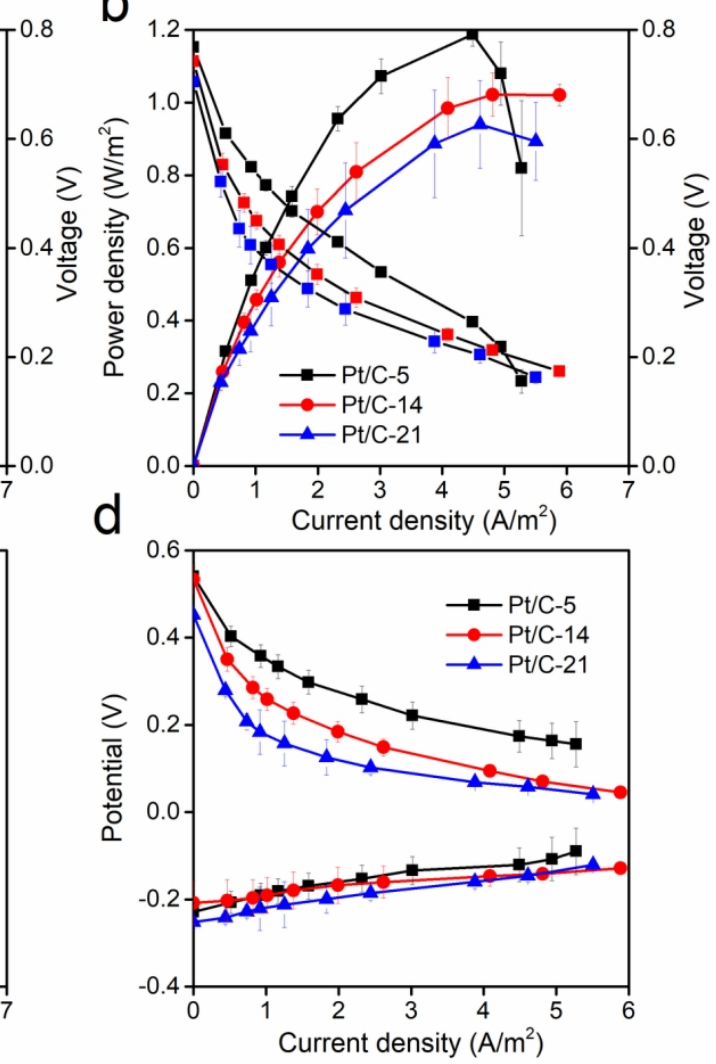

Fig. 6 Power denstiy

$146 \times 123 \mathrm{~mm}(300 \times 300 \mathrm{DPI})$ 